\title{
Students' Motivational Beliefs, Values and Goals as Related to Academic Hardiness: Implications to Mathematics Teaching and Learning
}

\author{
Edgardo M. Santos, Ph.D. ${ }^{1}$ \\ ${ }^{1}$ Vice President for Academic Affairs, Bulacan State University, City of Malolos Bulacan, Philippines, 3000
}

\begin{abstract}
Background/Objectives: The study examined the relationship between the Academic Hardiness and Motivational Beliefs, Goals and Values of tertiary students towards mathematics learning. The respondents of the study consist of about 167 BS Mathematics third year students of the Bulacan State University during Academic Year 2016-2017. The descriptive - correlational method of research was employed in the study. To gather the necessary data, the researcher adopted two instruments - the Academic Hardiness Scale developed by Benishek and Lopez (2001) and the Learning Motivation Questionnaire, a section from the Motivated Strategies for Learning Questionnaire (MSLQ) developed by Duncan and McKeachie (2005). Methods/Statistical analysis: Pearson correlation analysis and Test of significance were used to interpret the results. The study showed that among the three related attitudes of Academic Hardiness (Commitment, Control and Challenge), the students posted the highest mean in the Commitment domain. Seemingly, the difficulty posed by mathematics has not negated students' interest and involvement in doing their mathematical tasks. Findings: Regarding the status of the students' Motivational Beliefs, Goals and Values toward mathematics learning, results yielded a high overall mean rating reflective of the high ratings received in almost all the motivational constructs: Intrinsic Goal Orientation, Extrinsic Goal Orientation, Task Value, Controls of Learning Beliefs, SelfEfficacy for Learning and Performance except Test anxiety. The highest perceived mean is on Task Value which demonstrates the respondents expressed interest in mathematics and their acknowledge importance of the subject in their preparation to life-long learning. Improvements/Applications: For Test Anxiety, perceived mean rating is average. This result simply reiterates the psychological distress experienced by students when taking examinations in mathematics. Lastly, analysis also showed that students' Academic Hardiness and the identified motivational constructs has significant positive correlation with each other.
\end{abstract}

\section{Index Terms}

Academic hardiness, Mathematics teaching and learning, Motivational beliefs, Values and goals.

\footnotetext{
Corresponding author : Edgardo M. Santos

edgardo.santos@bulsu.edu.ph

- Manuscript received January 15, 2018.

- Revised February 26, 2018 ; Accepted March 2, 2018.

- Date of publication March 31, 2018.

(c) The Academic Society of Convergence Science Inc.

2546-1583 $\odot 2017$ IJEMR. Personal use is permitted, but republication/redistribution requires IJEMR permission.
} 


\section{INTRODUCTION}

Students' lack of interest and engagements in mathematics curricular tasks are glaringly complex and multifarious. Mathematics educators have taken innumerable initiatives and undertakings including research works, agenda and frameworks to confront the issue. Effects of psychological factors on classroom situations are also issues of growing concerns among mathematics educational researchers and practitioners. This could be attributed to inadequate scientific inquiry in some important factors in the above-mentioned areas of study. Many studies tend to approach psychological factors affecting mathematics classroom teaching and learning in a very general manner, hence results tend to be less applicable in real classroom set up.

Research has long seen the relationship between math anxiety and performance in mathematics. Avoidance of mathematics, passive engagements in classroom tasks and decline in mathematics performance are the effects of being anxious toward mathematics. Reference [1] revealed that mathematics anxiety has significant negative correlation with mathematics performance but no significant relationship with academic hardiness. However, these results were refuted in a separate study that showed mathematics anxiety having significant negative correlation with academic hardiness [2].

Academic hardiness is a personality characteristic that may differentiate students who avoid challenging academic course work from others who are willing to pursue these types of challenges [3]. A wide range of classroom based factors affect the quality of students' academic hardiness. It is found very important not only to students, but also to educational institutions and curriculum stakeholders. This construct has been conceptualized as comprised of three related attitudes, namely - commitment, control, and challenge [4]. Commitment refers to the individual's tendency to be involved, to have a sense of purpose, and to find meaning in one's activities and environment. Control is the perception that the individual can manage important life events through the use of imagination, knowledge, skills, and choice. Challenge is the perception that change, rather stability, is an accepted part of life, and necessary ingredient for personal development. The academic performance of every individual learner is believed to be influenced by these $3 \mathrm{C}$ 's. Hardiness is aptly described as a pathway to resilience under stress [5]. In fact, it has been pointed out that these elements of hardy attitudes can be a source of courage and motivation in converting stressful circumstances from potential threats into areas of strength and opportunities.

The role of motivation in making mathematics interesting and enjoyable for the students cannot be undermined. Research results showed the positive impact of motivation and good learning strategies on students' learning performance in mathematics. As studies have pointed out, educators should not look on motivation and learning strategies as static traits of the learner, but rather that motivation is dynamic and learning strategies can be learned and brought under the control of the students [6]. The main key here is for mathematics teachers to make the learning of the subject active, exploratory and fun by using a variety of instructional strategies coupled with technology, teaching aids and materials. Such techniques must take into consideration, learner's differences and attitudes towards mathematics as a subject.

The more recent theories of motivation focus specifically on the relation of beliefs, values, and goals with action. A proposed social cognitive model of motivation asserted that the intensity of an individual's motivation will trigger him to execute good or bad learning strategies [7,8]. The components of motivation in this model are value, expectancy and affect. Value consists of the goals and beliefs of the students concerning the importance and their appreciation of the task; expectancy refers to students' beliefs regarding their ability to do a task; and affect includes the students' emotional reactions to the task.

A number of theories focus on the distinction between intrinsic and extrinsic motivation. When individuals are intrinsically motivated, they engage in an activity because they are interested in and enjoy the activity. When extrinsically motivated, individuals engage in activities for instrumental or other reasons, such as receiving a reward.

Expectancy-based theories focus on individuals' beliefs about their competence and efficacy, expectancies for success or failure, and sense of control over outcomes. Reference [9] proposed a social cognitive model of motivation focused on the role of perceptions of efficacy. He defined selfefficacy as individuals' confidence in their ability to organize and execute a given course of action to solve a problem or accomplish a task. In 1995, a model of perceived control was proposed which focused on understanding goal-directed activity. The model described three critical beliefs: means-ends beliefs, control beliefs, and agency beliefs. Means-ends beliefs concern the expectation that particular causes can produce certain outcomes; agency beliefs are the expectations that one has access to the means needed to produce various outcomes; and control beliefs are the expectations individuals have that they can produce desired events [10].

An important component of a learner's engagement in an activity is task value. Task values are defined as 
individual's beliefs about value of doing the task. They include interest in the task, its importance to individuals and its utility [11]. Studies associating task values with student achievement showed inconsistent results. Reference [12] showed subjective task values being positively related to student achievement while reference [13] clarified that they are not predictors of achievement.

Test anxiety is a combination of perceived physiological over-arousal, feelings of worry and dread, self-depreciating thoughts, tension, and somatic symptoms that occur during test situations [14]. In a number of meta-analysis undertaken, it has been found out that test anxiety has negative effect on academic performance and is negatively related to achievement and self-esteem $[13,15]$.

The foregoing discussions underscores the need for a study that will guide teachers of mathematics to become models of inquiry and help them establish a teaching - learning environment in which they are motivated to make classroom mathematics instruction engaging and the students to improve their learning strategies by maximizing on their academic hardiness and reorienting their beliefs, goals and values towards mathematics learning.

\section{STATEMENT OF THE PROBLEM}

The general problem of the study is how do the mathematics students' motivational beliefs, goals and values relate with their academic hardiness.

Specifically, the study aims in finding answers to the following questions:

1. How may the academic hardiness of mathematics students be described in terms of the following attitudes?

\subsection{Commitment \\ 1.2 Control \\ 1.3 Challenge?}

2. What is the status of students' motivational beliefs, goals and values towards mathematics learning in terms of the following constructs?

2.1 Intrinsic Goal Orientation

2.2 Extrinsic Goal Orientation

2.3 Task Value

2.4 Controls of Learning and Beliefs

2.5 Self-Efficacy for Learning and Performance

2.6 Test Anxiety

3 . Is there significant relationship between academic hardiness and students' motivational beliefs, goals and values towards mathematics learning?

4. What are implications of the findings of the study on mathematics teaching and learning?

\section{CONCEPTUAL Framework OF THE STUdY}

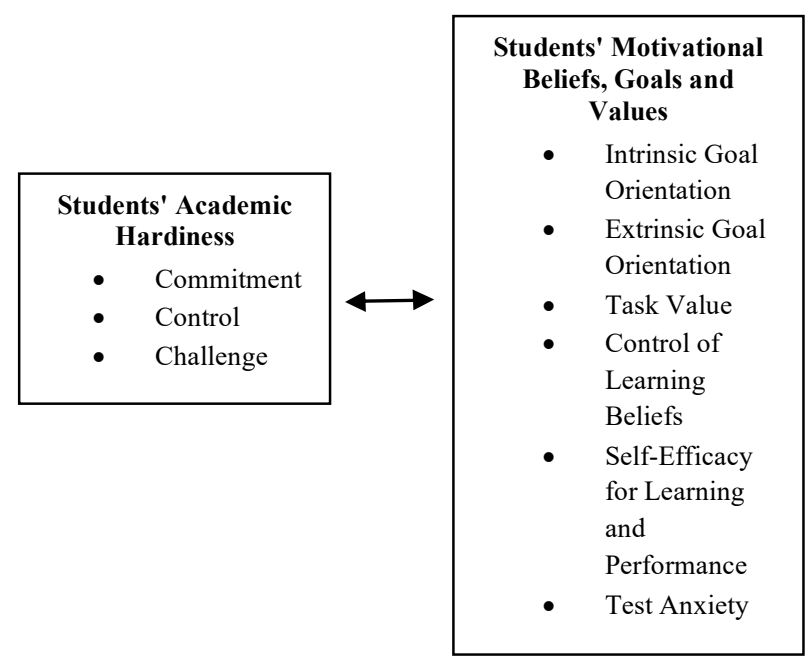

Fig. 1. which is based on the conceived educational insights from related literature and studies presents the conceptual framework of the study.

\section{MATERIALS AND METHODS}

The study made used of the descriptive survey method. A descriptive research design can be just as demanding in analytical skills as compared with the more idealized cause and effect study. The intent of the paper is to describe the characteristics of the identified population in terms of their perceived academic hardiness and status of motivational beliefs, goals and values as they learn mathematics. Furthermore, a correlation analysis between the two aforementioned variables was applied to determine the strength of their possible association.

The respondents of this study included 167 third year students of BS Mathematics with specialization in Business Applications and Applied Statistics enrolled during the second semester of the School Year 2016 - 2017 at the Bulacan State University.

The researcher used a 19 - item tool to assess the academic hardiness of the students. To fully measure the construct, the developed scale was subcategorized into: Commitment, Control and Challenge [16].

The other instrument used in the study is the Motivated Strategies for Learning Questionnaire (MSLQ). The validated tool consisting of 81 items and subdivided into two broad categories: (1) a motivation section and (2) a learning strategies section was designed to measure college students' motivational orientations and their use of various learning strategies [6]. For the purpose of this paper, only the Learning Motivation Questionnaire (motivation section) of the instrument was adopted. The section consists of 31 items that assess students' goals and value beliefs course, their beliefs about their skill to succeed in a 
course, and their anxiety about test in a course. The questionnaire is subcategorized into: Intrinsic Goal Orientation, Extrinsic Goal Orientation, Task Value, Control of Learning Beliefs, Self-Efficacy for Learning and Performance and Test anxiety.

Table 1. LeVEls of ACADEMIC HaRdiness and Learning STRATEGIES

\begin{tabular}{clll}
\hline $\begin{array}{c}\text { Likert } \\
\text { Scale }\end{array}$ & $\begin{array}{c}\text { Instrument } \\
\text { Rating }\end{array}$ & $\begin{array}{c}\text { Mean } \\
\text { Bracket }\end{array}$ & Interpretation \\
\hline 5 & Strongly Agree & $4.51-5.00$ & Very High Level \\
4 & Agree & $3.51-4.50$ & High Level \\
3 & Normal & $2.51-3.50$ & Average Level \\
2 & Disagree & $1.51-2.50$ & Low Level \\
1 & Strongly Disagree & $1.00-1.50$ & Very Low Level \\
\hline
\end{tabular}

The data and information gathered in the study were tallied, tabulated and processed through the computer system using the Statistical Package for Social Sciences (SPSS). To interpret raw score to the levels of academic hardiness and learning motivation, the equivalents in Table 1 are used.

\section{RESULT AND DISCUSSIONS}

This section deals with the presentation, analysis and interpretation of the results of the study on the students' academic hardiness and their motivational beliefs, goals and values towards mathematics learning.

\section{A. Descriptions of the Students' Academic Hardiness}

The level of academic hardiness of the students surveyed based on three components - commitment, control and challenge were measured descriptively through the mean and standard deviation. Table 2 describes the academic hardiness of the mathematics students. The results showed that commitment gathered the highest mean score of 3.85 with a standard deviation of 0.38 . This means that despite the hardships and struggles posed by their course, the BS Mathematics Business Applications and Applied Statistics students are still committed to learn mathematics seriously, be involved in mathematical tasks and work hard for their grades.

Table 2. DESCRIPTIONS OF STUDENTS' ACADEMIC HARDINESS

\begin{tabular}{lccc}
\hline $\begin{array}{l}\text { Domains of the } \\
\text { Students }\end{array}$ & & Standard & \\
$\begin{array}{l}\text { Academic } \\
\text { Hardiness }\end{array}$ & Mean & Deviation & Interpretation \\
\hline Commitment & 3.85 & 0.38 & High \\
Control & 3.09 & 0.17 & Average \\
Challenge & 3.44 & 0.46 & Average \\
\hline
\end{tabular}

The component which obtained the next highest score is challenge with the rating of 3.44 but with a relatively large value of 0.46 for the standard deviation. This shows that students have average positive attitude towards the challenges encountered in mathematics classroom. They moderately accept the idea that difficult subjects are the best way to improve one's mathematical knowledge. Control has the lowest mean score of 3.09 but with the least standard deviation of 0.17 . In terms of this construct, students are on the average level. Hence, students sometimes doubt themselves when facing difficulties in their mathematics classes. They become motivated less when they fail to get the grades that they want.

\section{B. Status of Students' Motivational Beliefs, Goals and Values}

Table 3 below displays the status of the students' motivational beliefs, goals and values towards mathematics learning of the mathematics students. The overall mean for the category is 3.84 with a standard deviation of 0.23 . Clearly, the results describe the respondents as having a high motivation towards mathematics learning.

Table 3. MEAN OF FACTORS Under Students' Motivational Beliefs, Goals AND VAlues

\begin{tabular}{|c|c|c|c|}
\hline $\begin{array}{l}\text { Subscales of } \\
\text { Students' } \\
\text { Motivational } \\
\text { Beliefs, Goals and } \\
\text { Values }\end{array}$ & Mean & $\begin{array}{l}\text { Standard } \\
\text { Deviation }\end{array}$ & Interpretation \\
\hline $\begin{array}{l}\text { Intrinsic Goal } \\
\text { Motivation }\end{array}$ & 3.94 & 0.16 & High \\
\hline $\begin{array}{l}\text { Extrinsic Goal } \\
\text { Motivation }\end{array}$ & 3.92 & 0.09 & High \\
\hline Task Value & 4.03 & 0.09 & High \\
\hline $\begin{array}{l}\text { Control of Learning } \\
\text { and Beliefs }\end{array}$ & 3.92 & 0.16 & High \\
\hline $\begin{array}{l}\text { Self-Efficacy for } \\
\text { Learning } \\
\text { And Performance }\end{array}$ & 3.81 & 0.10 & High \\
\hline Test Anxiety & 3.39 & 0.15 & Average \\
\hline $\begin{array}{l}\text { Overall Learning } \\
\text { Motivation }\end{array}$ & 3.84 & 0.23 & High \\
\hline
\end{tabular}

Among the six indicators of learning motivation, Task value has the highest mean with a value of 4.03, interpreted as high level. Standard deviation is low at 0.09 . This indicates that students are confident that what they are learning in the course will be needed in their future careers. Furthermore, respondents have noted that the classroom learning tasks and course materials being used are useful for their learning.

For the construct Intrinsic goal orientation, the mean value of 3.94 at a standard deviation of 0.16 , indicates a high level of motivation. It can be said that students personally want to excel or learn more about mathematics because they want to feel good about themselves. Respondents find it satisfying if they will have a thorough understanding of the required mathematical concepts, hence challenging tasks and 
assignments are acceptable. Personal satisfaction and self-development to prepare students for their future may be some of the motivating reasons.

Extrinsic goal orientation and Control of learning beliefs both have high level of motivation with a shared mean of 3.92. The two constructs have standard deviations of 0.09 and 0.16 , respectively. Such high level of extrinsic goal orientation is an indication that the respondents wants to do well in the class to show their ability to family members, friends and immediate circle of individuals. This could be manifested by way of improving their grades with the use of varied and appropriate strategies for learning. The high level of students' Control of their learning and beliefs provides them motivation to do independent learning. Moreover, student - respondents believe that the hard work that they put into will yield positive results.

The Self-efficacy for learning and performance got a mean rating of 3.81. This score was associated with a standard deviation of 0.10 . The mean score for this construct is not that good but still falls under the high level of motivation, which indicates that at their present academic level, the respondents are sufficiently confident that they would be able to accomplish their tasks, have the skill to understand even the most complex concepts and materials to be presented by their teachers and consequently, obtained excellent grades.

The least mean score was obtained by the construct - Test anxiety. It is the only factor that posted an average level of motivation. Mean and standard deviation were pegged at 3.39 and 0.15 respectively. This indicates that students somehow feel anxious whenever taking examinations. Many immediately think about the consequence of failing and readily label themselves inferior as compared to others.

\section{The Correlation between Students' Academic Hardiness and their Motivational Beliefs, Goals and Values towards Mathematics Learning}

Table 4 shows the correlation coefficient between Academic Hardiness and students' Motivational Beliefs, Goals, and Values towards mathematics learning of 0.40 . The data shows that these motivational constructs have significant relationship with Academic hardiness. Results showed a p-value of 0.00 which is less than the 0.05 level of significance.

Table 4. CORRELATION BETWEen STUDENTS' ACADEMIC HARDINESS AND THEIR MOTIVATIONAL BELIEFS, GOALS, AND VALUES TOWARDS MATHEMATICS LEARNING

\begin{tabular}{llll}
\hline Academic & Pearson $\mathrm{r}$ & $\begin{array}{l}\text { Sig. (2- } \\
\text { tailed) }\end{array}$ & Interpretation \\
Hardiness & & & \\
\hline
\end{tabular}

Motivational

\begin{tabular}{llll}
\hline $\begin{array}{l}\text { Beliefs, } \\
\text { Goals and Values }\end{array}$ & 0.40 & 0.00 & Significant \\
\hline
\end{tabular}

Table 5 shows that out of 3 attitudes under Academic hardiness, only 2 have been proven with significant relation with Intrinsic goal orientation. These are commitment and challenge having the p-values of 0.00 and 0.02 respectively. These values are less than the set level of significance which is 0.05 .

Table 5. CORRELATION BETWEen STUdents' InTRINSIC GOAL ORIENTATION AND THEIR ACADEMIC HARDINESS

\begin{tabular}{lcll}
\hline $\begin{array}{l}\text { Intrinsic Goal } \\
\text { Orientation in } \\
\text { relation to: }\end{array}$ & Pearson r & $\begin{array}{l}\text { Sig. (2- } \\
\text { tailed) }\end{array}$ & Interpretation \\
\hline Commitment & 0.30 & 0.00 & Significant \\
Control & -0.05 & 0.53 & Not Significant \\
Challenge & 0.18 & 0.02 & Significant \\
\hline
\end{tabular}

The results imply that intrinsic motivation shows learners commitment in learning for personal interest. Moreover, students tend to be challenged by mathematical tasks and course materials where they can learn new things.

Table 6 shows the significant and non-significant factors of Academic hardiness affected by the Extrinsic goal orientation. Challenge has no significant relation with the Extrinsic goal orientation because its $p$-value is greater than 0.05 , however Commitment and control are said to be of significant correlation with the construct.

Table 6. Correlation Between StUdents' Extrinsic GoAl ORIENTATION AND THEIR ACADEMIC HARDINESS

\begin{tabular}{llll}
\hline $\begin{array}{l}\text { Extrinsic Goal } \\
\begin{array}{l}\text { Orientation in } \\
\text { relation to: }\end{array}\end{array}$ & Pearson $\mathrm{r}$ & $\begin{array}{l}\text { Sig. } \\
(2- \\
\text { tailed })\end{array}$ & Interpretation \\
\hline Commitment & 0.40 & 0.00 & Significant \\
Control & 0.18 & 0.02 & Significant \\
Challenge & 0.14 & 0.22 & Not Significant \\
\hline
\end{tabular}

The computed values revealed that teachers can make use extensively of extrinsic goal orientation to motivate students to enhance their commitment to mathematics learning. Similarly, this mode of motivation can negate the effects of academic disappointments resulting from failing from a mathematical assessment or getting grades.

The data displayed on Table 7 shows that Commitment and challenge have significant effect on Task value with p-values of 0.000 and 0.004 respectively at 0.05 level of significance.

Table 7. Correlation Between STUdents' TASK VAlues AND THEIR ACADEMIC HARDINESS 


\begin{tabular}{llll}
\hline $\begin{array}{l}\text { Task Value } \\
\text { in relation to: }\end{array}$ & Pearson $\mathrm{r}$ & $\begin{array}{l}\text { Sig. }(2- \\
\text { tailed) }\end{array}$ & Interpretation \\
\hline Commitment & 0.38 & 0.00 & Significant \\
Control & -0.06 & 0.43 & Not Significant \\
Challenge & 0.22 & 0.004 & Significant \\
\hline
\end{tabular}

Analysis indicates that students may commit themselves to do mathematical activities in which they attach more value simply because they perform very well in them. Moreover, student - respondents seemingly enjoy the challenge posed by difficult subjects like mathematics.

Commitment and challenge have significant correlation not only with intrinsic goal orientation and task value but as well with students' control of learning beliefs. Table 8 shows this observation at 0.00 and $0.001 \mathrm{p}-$ values respectively which is less than 0.05 level of significance.

Table 8. Correlation Between Students' Control of LEARNING BELIEFS AND THEIR ACADEMIC HARDINESS

Control of

\begin{tabular}{llll}
$\begin{array}{l}\text { Learning } \\
\text { Beliefs in } \\
\text { relation to: }\end{array}$ & Pearson $\mathrm{r}$ & $\begin{array}{l}\text { Sig. } \\
(2-\end{array}$ & Interpretation \\
tailed $)$ & \\
\hline Commitment & 0.35 & 0.00 & Significant \\
Control & 0.12 & 0.12 & Not Significant \\
Challenge & 0.26 & 0.001 & Significant \\
\hline
\end{tabular}

Results seem to support findings which suggested that students who can control their achievement outcomes is more committed to attain their competence needs [17]. Once these needs are fulfilled, the more students will be engaged and challenged in doing difficult mathematical tasks.

Table 9. Correlation BetweEn STUdents' SElF-EFFiCACy FOR LEARNING AND PERFORMANCE AND THEIR ACADEMIC HARDINESS

\begin{tabular}{llll}
\hline $\begin{array}{l}\text { Self-Efficacy } \\
\text { for Learning } \\
\text { and }\end{array}$ & & \multicolumn{1}{l}{$\begin{array}{l}\text { Sig. }(2- \\
\text { tailed) }\end{array}$} & Interpretation \\
$\begin{array}{l}\text { Performance } \\
\text { in relation to: }\end{array}$ & Pearson $\mathrm{r}$ & & \\
\hline Commitment & 0.25 & 0.001 & Significant \\
Control & 0.11 & 0.15 & Not Significant \\
Challenge & 0.22 & 0.004 & Significant \\
\hline
\end{tabular}

Table 9 shows that Self - efficacy for learning and performance has significant positive correlation with commitment and challenge domains of Academic hardiness at $\mathrm{p}-$ values ranging from $0.001-0.004$. However, control shows non-significant relation with the same construct because its p-value is greater than 0.05 .

From the results, one can deduce that the mathematics students in the study are efficacious even at the most challenging and difficult tasks. More than that, their sense of self-efficacy for learning and performance can be considered as determinant for the students' commitment and expectancy for success.

Table 10 shows that all factors under Academic hardiness are significantly correlated with Test Anxiety. The constructs commitment, control and challenge have p-values of $0.031,0.000$ and 0.003 respectively, which are all less than 0.05 level of significance.

Table 10. Correlation BETWEen STUDENTS' Test ANXIETy AND THEIR ACADEMIC HARDINESS

\begin{tabular}{llll}
$\begin{array}{l}\text { Test Anxiety } \\
\text { in relation to: }\end{array}$ & Pearson $\mathrm{r}$ & $\begin{array}{l}\text { Sig. (2- } \\
\text { tailed) }\end{array}$ & Interpretation \\
\hline Commitment & 0.17 & 0.031 & Significant \\
Control & 0.44 & 0.00 & Significant \\
Challenge & 0.23 & 0.003 & Significant \\
\hline
\end{tabular}

The significant correlation between Academic hardiness and Mathematics performance has been validated by numerous studies but the present study has revealed that mathematics students with hardy attitudes despite being test anxious will be more motivated to learn challenging learning materials, more strongly committed to their studies than those simply attending classes but not having hardy attitudes and more in control in a stressful academic situation rather than withdraw from it.

\section{CONCLUSION AND RECOMMENDATIONS}

The present study showed the significant correlation between students' Academic Hardiness and their Motivational Beliefs, Goals and Values towards mathematics teaching and learning. Results of the study indicate that the interactions among the component attitudes of commitment, control and challenge and the various subscales of intrinsic and extrinsic goal motivation, task values, control of learning and beliefs, self-efficacy for learning and performance and test anxiety influence in varying levels the ways in which students approach the mathematical tasks given them, persist in confronting the difficulties posed by these tasks and appreciate the task -outcomes.

An analysis of the students' responses suggests the following implications for mathematics learning: (1) learners with strong mathematics commitment can transform stressful learning situations into growth learning opportunities; (2) those with strong control attitude are able to manage their studies and take responsibility for their own learning and growth in mathematics; (3) while students with high challenge attitude will look on potentially threatening mathematics classroom circumstances as stimulating opportunity for learning in the subject 
The present study has validated claims in previous studies regarding the significant role of motivation in the learning process of the students. Based from the perceptions of the mathematics students surveyed, the subscales of motivational beliefs, values and goals help them gauge how much value, effort and interest they will put into the mathematical task. Many mathematics students either lack motivation to work on classroom learning task or are dependent on extrinsic motivation to survive the challenges of mathematics. However, students with high motivation have positive attitudes such as being able to maintain intrinsic interest and regulate their own learning; thereby enhancing their self-efficacy.

The findings of the study have implications as well for the mathematics teachers to improve present status of mathematics classroom practices and management. Teachers can also employ personality development strategies to enhance student motivation that will enable them to do better mathematics and think mathematically.

Cognizant of the fact that students' motivations are teachable, mathematics educators should train their students to employ strategies that will help them develop constructive beliefs on intrinsic goal orientation, self-efficacy for learning and performance, task value and control of learning beliefs.

With the students at the center of the teaching and learning setting, mathematics teachers should continuously remind their students in fitting their academic hardiness and motivational beliefs, goals and values to suit their mode of learning, thereby enhancing achievement in mathematics.

Lastly, mathematics teachers should encourage students to believe in their potential in the subject and only them could bring about the realization of these potentials. This positive attitude towards the subject is part of the bigger goal of equipping students with the right dispositions for lifelong learning.

\section{ACKNOWLEDGMENT}

The author would like to thank his BS Mathematics students for the Academic Year 2016 2017 for the assistance given during the collection and processing of the research data. The same appreciation is extended to Dr. Cecilia Geronimo, Vice President for Research, Extension and Training for the support given to this endeavor.

\section{REFERENCES}

[1] Karimi, A., \& Venkatesan, S. (2009). Mathematics Anxiety, Mathematics Performance and Academic Hardiness in High School Students. Int J Edu Sci, 1(1), 33-37.

[2] Daneshamooz S. \& Alamolhodaei. (2012). Cooperative learning and academic hardiness on students' mathematical performance with different levels of mathematics anxiety. Educational Research (ISSN: 2141-5161) 3, 270-276.

[3] Kamtsios, S., \& Karagiannopoulou, E. (2011). Psychometric characteristics of the "Academic Hardiness Scale" in a Greek sample: a pilot study. Scientific Annals, School Psychology, Aristotle University Thessaloniki, 8, 67-88.

[4] Kobasa, S.C., Maddi, S.R., \& Kahn, S. (1982). Hardiness and health: A perspective study. Journal of Personality and Social Psychology, 42, 168-177.

[5] Maddi, S. (2006). Hardiness: the courage to grow from stresses. The Journal of Positive Psychology, 1(3),160-168.

[6] Duncan, T. G., \& McKeachie, W. J. (2005). The making of the Motivated Strategies for Learning Questionnaire. Educational Psychologist, 40(2), 117-128.

[7] Pintrich, P. R., De Groot, E. V. (1990). Motivational and selfregulated learning component of classroom academic performance. Journal of Educational Psychology, 82, 33-40.

[8] Liu, E. Z. F., \& Lin, C. H. (2010). The survey study of mathematics motivated strategies for learning questionnaire (MMSLQ) for grade 10-12 Taiwanese students. TOJET, 9(2). Retrieved on February 5, 2015 from http://goo.gl/zogffR

[9] Bandura, A. (1997). Self -Efficacy: The exercise of control. New York: Freeman.

[10] Skinner, E. \& Greene, T. Perceived Control Perceived Control: Engagement, Coping, and Development, 21st century education: a reference handbook, 1, 121-130.

[11] Wigfield, A., Eccles, J. S., Yoon, K. S., Harold, R. D.,Arbreton, A., Freedman-Doan, C., et al (1997). Changes in children's competence beliefs and subjective task values across the elementary school years: A three-year study. Journal of Educational Psychology, 89, 451-469.

[12] Eccles, J. S. (2005). Subjective task values and the Eccles et al. model of achievement related choices. In A. J. Elliot \& C. S. Dweck (Eds.), Handbook of competence and motivation (pp. 105-121). New York: Guilford.

[13] Pintrich, P. R., \& Schunk, D. H. (2002). Motivation in education: Theory, research, and applications (2nd ed.). Upper Saddle River, NJ: Prentice Hall.

[14] Rajiah K. et al (2014). The Effectiveness of Psychoeducation and Systematic Desensitization to Reduce Test Anxiety among First-year Pharmacy Students. American Journal of Pharmaceutical Education. Volume 78(9).

[15] Hembree, R. (1088). Correlates, causes, effects, and treatment of test anxiety. Review of Educational Research, 58(1), 47-77.

[16] Benishek, L. A., Feldman, J. M., Wolf-Shipon, R. W., Mecham, S. D, \& Lopez, F. G. (2005). Development and evaluation of the revised academic hardiness scale. Journal of Career Assessment, 13(1), 59-76.

[17] Connell, J. P., \& Wellborn, J. G. (1991). Competence, autonomy and relatedness: A motivational analysis of selfsystem processes. In M. Gunnar \& L. A. Sroufe (Eds.), Minnesota Symposium on Child Psychology: Vol. 23. Selfprocesses in development (pp. 43-77). Chicago: University of Chicago Press 